TIGG Vol.2 No.8 (1990)

TBCANICAL NOTE (TIGG-11/02/90-TN-1)

\title{
Derivatization of Oligosaccharides from Glycosphingolipids with Aminobenzoic Acid Ethyl Ester and Analysis of Saccharide Structure of Glycosphingolipids by Two-Dimensional Mapping with High Performance Liquid Chromatography
}

\author{
Hideyoshi HIGASHI \\ Laboratory of Glycoconjugate Research, \\ Mitsubishi Kasei Institute of Life Sciences, \\ 11, Minamiooya, Machida-shi, Tokyo 194, Japan, FAX: 81-427-29-1252
}

Analytical methods for determining the saccharide structures of glycosphingolipids have been improved and most structures can be determined completely by permethylation analysis, mass spectrometry, and NMR. However, since a certain amount (usually more than $100 \mu \mathrm{g}$ ) of a purified glycosphingolipid must be available for analysis by these methods, a too small amount will present difficulties. Recently, we developed a method for analysis of saccharide structures that requires only small amounts of glycosphingolipid mixtures by two-dimensional mapping of oligosaccharides from glycosphingolipids with HPLC [1] and is introduced in this article. Generally, it is difficult to separate glycosphingolipids whose saccharides are similar in structure by chromatography since naturally occurring single species of glycosphingolipid are mixtures of molecules consisting of various ceramide portions. This leads to various complex patterns of separation on chromatography. To avoid this difficulty the ceramide portion is eliminated from saccharide portions of glycosphingolipids. Recently, Ito and Yamagata discovered endoglycoceramidase (EGCase) which cleaves glycosidic linkage between saccharide portion and the ceramide portion of glycosphingolipids selectively [2, 3] and this enzyme should thus make it possible to obtain oligosaccharides from glycosphingolipids much more easily and efficiently than the previously used method of ozonolysis. Ito has described a method for hydrolysis using endoglycoceramidase in this journal recently [4]. The oligosaccharides obtained were labelled with an ultra-violet absorbent, paminobenzoic acid ethyl ester (ABEE). Another labelling method, 2-aminopyridyl (2AP) derivatization was tested but found unsuitable for analysis of relatively short chain saccharides, particularly those that are acidic since clear separation using presently available HPLC columns was quite difficult. ABEE-labelled oligosaccharides can be mapped two-dimensionally using a TSKGEL Amide 80 column (TOSOH, Tokyo, Japan), and a Wakosil 5C4 column (Wako Pure Chemicals Ltd., Osaka, Japan) for HPLC. By an Amide 80 column, acidic oligosaccharides could be separated completely from neutral ones for analysis of the latter.

\section{ABEE-labelling of oligosacharides}

We diluted the original reagent described by wang et al. [5] to make purification easy after the labelling reaction and prevent the degradation of sialyl residues of oligosaccharides as follows: As much as $100 \mathrm{nmol}$ of dried oligosaccharides and the following reagents below are mixed, sealed and heated at $80^{\circ} \mathrm{C}$ for $90 \mathrm{~min}$. 


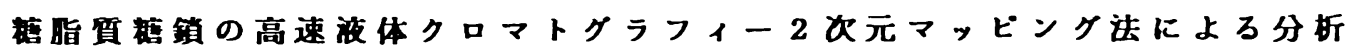

\section{東秀好}

糖脂質の糖鎖構造解析技術は、非常に進歩 し、メチル化分析、マススペクトロメトリー （MS）、NMR分析などを行えば、ほとんどの構造 は決定されるようになった。ところが、これ らの分析を行う場合、純粋な糖脂質を比較的 大量に用意する必要があるので、特に微量な 試料の分析は困難である。私たちは、最近、 高速液体クロマトグラフィー(HPLC)を用いる ことによって、糖脂質糖鎖の構造をマップ化 し、微量の混合試料の構造解析を行う方法 [1] を開発したので、ここで解説したい。一般に 一種類のスフィンゴ糖脂質は異なるセラミド 分子を有する混合物であるので、糖脂質の状 態での糖鎖構造の解析においてセラミド部分 の不均一性がしばしば障害となり、特にク口 マトグラフィーにおいて類似の糖鎖構造を持 つ榶脂質の分離は困難である。そこで、糖脂 質の糖鎖をセラミドから切り出す必要がある。 糖脂質からオリゴ榶を得る方法としては、従 来、オゾン分解法しかなかったが、最近、工 ンドグリコセラミダーゼという醉素が発見さ れた $[2,3]$ 。私たちの研究室の伊東と山形が 発見したエンドグリコセラミダーゼは、スフ ィンゴ榶脂質の榶鎖とセラミドの間のグリコ シド結合を選択的に切断するので、糖脂質由 来のオリゴ榶をオソン分解法に比して、容易
に効率良く得ることができる。この方法につ いては、本誌 Vol. 2 No. 7 の伊東のテクニ カルノートを参照されたい[4]。こうして得ら れたオリゴ糖は、HPLCで高感度に検出するた めに、紫外吸収物質であるp-アミノ安息香酸

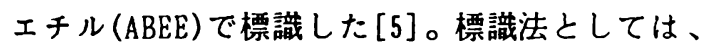
2 アミノピリジル化といった蛍光標識法もあ るが、現在のところ、糖脂質の様に比較的短い 糖鎖、特に酸性の糖鎖の構造の違いをHPLCで 分離するに限っていえば、カラム等分離技術 の問題からもABEE化のほうが有利である。こ うして得られたABEE化オリゴ糖は、TSK-GEL Amide80 (TOSOH)、Wakosil 5C4 (和光純薬)、 2 種類のHPLCカラムによってマッピングする のであるが、Amide80では、酸性のオリゴ榶は、 中性のオリゴ糖分析時に完全に中性オリゴ榶 から分離することができる。

\section{1.オリゴ糖のABEE化}

反応後の精製を容易にするためとシアル酸の 脱離を防ぐために反応試薬は、Wang らの原法 [5]より薄いものを用いる。100 nmol までの 乾燥したオリコ糖に対して、以下の試薬を加 えて密閉し、80度で90分加熱する。 
TIGG Vol.2 No.8 (1990)

THCHNICAL NOTE (TIGG-11/02/90-TN-1)

Methanol

ABBE (20 mg/ml methanol) 14

$\mathrm{NaBH} 3 \mathrm{C}_{3} \mathrm{C} 2 \mathrm{mg} / \mathrm{ml}$ methanol) 14

18 acetic acid/methanol 16

Total

70

In this manner, $80 \$ 90 \%$ of the oligosaccharides was labelled and less than $1 \%$ of the sialyl residues released. After cooling, the reaction mixture is dried under nitrogen gas at room temperature and then dissolved in chloroform/methanol $(2: 1)$ and loaded onto a $1 \mathrm{ml}$ column of Phenylboronate agarose (PBA60, Amicon Co., Danvers, MA) equibilized in the same solvent. Since ABEE-oligosaccharides is absorbed by this column, the un-reacted reagents and salts are washed out with $2.5 \mathrm{ml}$ of the same solvent. ABEE-oligosaccharides are then eluted from the column with $5 \mathrm{ml}$ of chloroform/methanol/water (2:8:5). The ABEE-oligosaccharides obtained in this way can be analyzed directly by FAB-MS since not only most of the unreacted reagent but the salts as well can be eliminated by this step. A PBA60 column can be re-used after being dehydrized with methanol.

\section{Two-dimensional HPLC}

$A B E E-o l i g o s a c c h a r i d e s$ are chromatographed first on the Amide 80 column (4.6 $0 \times 250 \mathrm{~mm})$ using acetoni $(50: 50) / 20 \mathrm{~min}, 1 \mathrm{ml} / \mathrm{min}$. Acidic ABEEoligosaccharides are eluted in a void volume earlier than any neutral $A B E E-$ oligosaccharides. In neutral ABEEoligosaccharides, shorter oligosaccharides are eluted earlier. The acidic ABEE-oligosaccharides are eluted in the same manner when using the same solvent system which contains aqueous $10 \mathrm{mM}$ $\mathrm{KH}_{2} \mathrm{PO} 4$ instead of water. ABEE-oligosaccharides separated on the Amide 80 column are each fractionated in the amount of $1 \mathrm{ml}$ and all the fractions

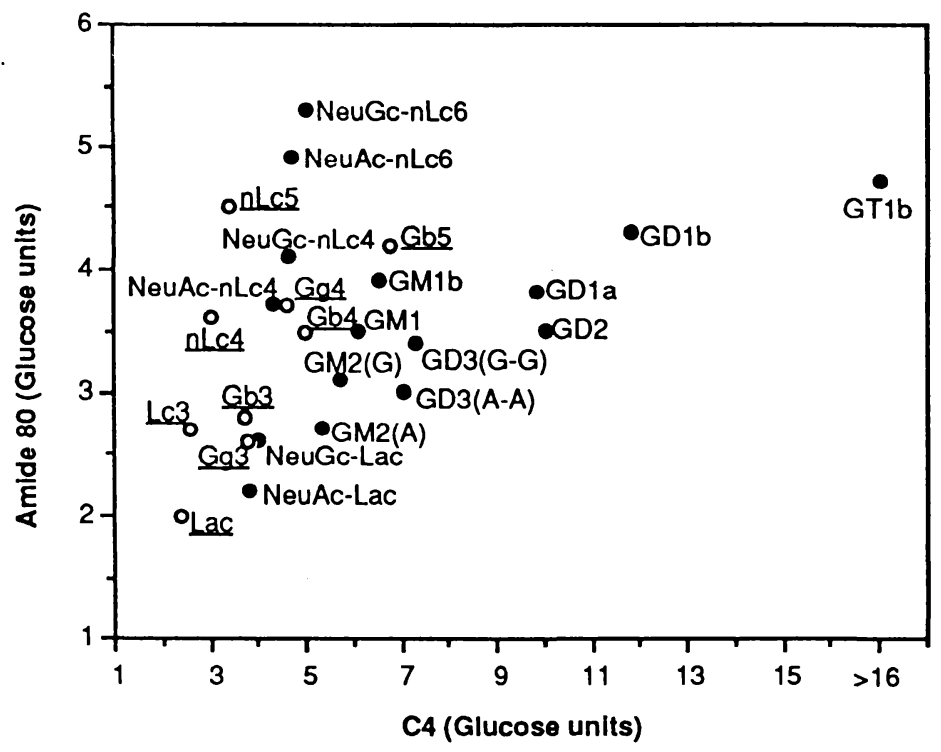

Fig. 1 Two-dimensional map by HPLC of standard

ABEE-oligosaccharides derived from neutral $(\mathrm{O})$ and acidic glycosphingolipids ( $)$. 


$$
\text { メタノール }
$$

$\operatorname{ABEE}(20 \mathrm{mg} / \mathrm{ml} メ タ ノ ー ル)$ 14

$\mathrm{NaBH}_{3} \mathrm{CN}(2 \mathrm{mg} / \mathrm{ml}$ ×タノール)

14

$1 \%$ 酢酸/メタノール

\section{合計 70}

この条件では、80〜90\%のオリゴ榶がABEE化 され、シアル酸の遊離は1\%以下である。冷却 後、室温にて窒素ガスを用いて乾燥する。こ れをクロロフォルムーメタノール(2:1)に溶か し、同溶媒に愫濁したフェニルボロネイトアガ ロースカラム(PBA60、Amicon社) $1 \mathrm{mlkかけ}$ る。ABEE化オリゴ榶はこのカラムに吸着され るので、未反応の試薬や塩は同溶媒 $2.5 \mathrm{ml}$ 洗い流す。ABEE化オリゴ榶は、クロロフォル ムーメタノールー水 (2:8：5）5 m1でカラムか ら回収される。この操作によって、未反応の 試薬がほとんど除かれるほか、塩が除かれる ので、得られた試料をFAB-MS 分析することる 可能である。なお、PBA60カラムは、メタノー ルで脱水して再使用できる。

\section{2次元HPLC}

ABEE化オリゴ榶は、まず、Amide80 カラム

$(4.6 \phi \times 250 \mathrm{~mm})$ でアセトニトリルー水 $(75: 25)$ $\rightarrow(50: 50) / 20$ 分、1 m1/分の条件でクロマ トグラフィーを行う。ガングリオシド由来の 酸性オリゴ榶はどの中性オリゴ糖よりも先に 溶出され、ついで中性オリゴ糖がその榶鎖の 小さい順に溶出される。酸性オリゴ榶は、同
じカラムで同じ溶媒系の水の代わりに $10 \mathrm{mM}$ $\mathrm{KH}_{2} \mathrm{PO}_{4}$ 水溶液を用いると糖鎖の小さい順に分 離溶出する。Amide80で分離したオリゴ糖は、 $1 \mathrm{ml}$ ずつの画分として分取し、各画分をC4 ラム $(4.6 \phi \times 250 \mathrm{~mm})$ で $50 \mathrm{mM} \mathrm{KH}{ }_{2} \mathrm{PO}_{4}$ 中nーブタノ 一ルを $4 \rightarrow 8 \% / 20$ 分で変化させ、 $1 \mathrm{ml} /$ 分の条 件でクロマトグラフィーを行う。このクロマ トグラフィーでは、同じシリーズに属する糖 鎖は、糖銷の大きい順に溶出されてくる。こ の方法で代表的な糖脂質のオリゴ糖について 分析し、各クロマトグラフィーにおける溶出 時間をグルコース単位で表わして 2 次元マッ プとしたのがFig. 1である。中性と酸性の才 リゴ糖が別個に分析できるので、9種の中性及 び16種の酸性オリゴ糖が、オーバーラップな しにマッピングされているのがわかる。グル コース単位はABEE化イソマルトオリゴ糖の溶 出時間を基準にして、溶出時間とグルコース の数の関係を直線で結んだ標準線から得た。 Amide80, Wakosil C4 とも、糖鎖の大きさと構 成糖及び結合様式の違いで分離したが、特に、 Amide80はシアル酸の種類による分離が顕著で、 Wakosil C 4 では中性、酸性とるにネオラクト シリーズの嵣鎖がグロボシリーズやガングリ オシリーズの糖鎖に比べて溶出が極めて遅か った。

多くの試料の分析に対応するためには、才 リゴ糖のデータを增やしていかなければなら ないが、この標準マップ上にない未知のオリ ゴ榶についても、シフリダーゼやガラクトシ 
TIGG Vol.2 No.8 (1990)

TFCHNICAL NOTE (TIGG-11/02/90-TN-1)

are chromatographed on a C4 column $(4.6$ o x $250 \mathrm{~mm}$ ) using a linear gradient of n-butanol, 4- $88 / 20 \mathrm{~min}$ in $50 \mathrm{~mm}$ $\mathrm{KH} 2 \mathrm{PO} 4,1 \mathrm{ml} / \mathrm{min}$. In this chromatography, larger oligosaccharides of the same series are eluted earlier. Fig. 1 shows a two-dimensional map of standard oligosaccharides from glycosphingolipids plotted against elution time and expressed as glucose units. $\mathrm{ABEE}$-and 16 acidic oligosaccharides were mapped perfectly without any overlapping since neutral and acidic oligosaccharides could be analyzed separately. The glucose units were obtained from a standard line graph of elution time versus glucose number for ABEE-isomalto-oligosacchàrides. ABEE-oligosaccharides were separated according to size and structure on both Amide 80 and C4 columns. Amide 80 clearly separated the sialic acid species. Both neutral and acidic neolacto-series' oligosaccharides were eluted much more slowly than the other series of oligosaccharides from the $\mathrm{C} 4$ column.

The number of standard ABEEoligosaccharides must be increased on two-dimensional map for analysis of various samples. However, it is possible to characterize some structures without the standard on the map when the effects of glycosidases, such as sialidase and galactosidases are exerted on the coordinates of the map. ABEE-oligosaccharides were much more sensitive toward glycosidases than their parent glycosphingolipids and required no detergent. Interestingly, the branched sialyl residues of $A B E E-$ oligosaccharides of GM1 and GM2 also showed some resistance against the sialidase of Arthrobacter ureafaciens. $A B E E-o l i g o s a c c h a r i d e s$ give rise to strong ion peaks in FAB-MS analysis [5, 6 ] and less than 100 pmol of a sample could be analyzed. FAB-MS analysis should provide useful information for determination of unknown samples.

ABEE-oligosaccharides can be detected in amounts as small as several pico mole and are of use for the quantitative determination of each component since they possess constant molar absorption coefficients when a hexose is present in the reducing end of the oligosaccharides [6]. By this method, both the compositions and structures of glycosphingolipids can be easily determined for sample available in small amounts, except in the case of cerebroside and sulfatide which are not susceptible to EGCase. The availability of LC-MS and third chromatography will improve this method.

\section{References}

1. Higashi, H., Ito, M., Fukaya, N., Yamagata, S., and Yamagata, T. (1990) Anal. Biochem. 186, 355362

2. Ito, M., and Yamagata, T. (1986) J. Biol. Chem. 261, 14278-14282

3. Ito, M., and Yamagata, T. (1989) J. Biol. Chem. 264, 9510-9519

4. Ito, M. (1990) TIGG. 2, 399-402

5. Wang, W. T., LeDonne, N.C., Jr., Ackerman, B., and Sweeley, C.C. (1984) Anal. Biochen. 141, 366381

6. Matsuura, F., and Imaoka, A. (1988) Glycoconjugate J. $\underline{5}, 13-26$ 
ダーゼを用いてマップ上での挙動の変化を調 べることによりある程度まで構造を知ること ができる。この場合、ABEE化オリゴ榶は、糖 脂質に比へててこようなグリコシダーゼに対 する感受性が高くディタージェント等を必要 としない。興味深いことに、ABEE化オリゴ糖 の場合も、GM2や、GM1の榶鎖途中のガラクト ースについたシアル酸残基は、榶鎖末端のそ れに比較して Arthrobactor uraafacians $の$ シアリダーゼに対して抵抗性であった。また、 ABEE化オリゴ糖は、FAB-MS分析において、大 きなイオンピークを与えることが知られてお り[5, 6]、100 pmol以下の試料で測定可能で ある。未知物質の構造解析には強力な手段で
ある。

ABEE化オリゴ榶は、1 ピーク数ピコモルの 感度で検出でき、這元末端にヘキソースを持 つオリゴ糖は、一定の分子吸光係数を持つの で[6]、定量にも便利である。本法により、従 来のクロマトグラフィーや免度化学的手法で は困難であった少量の試料中の榶脂質の全体 像と糖鎖構造の解析が、EGCaseに分解されな いセレブドシド、スルファチド以外のすべて について簡便に行えるようになったと考える。 今後、ABEE化オリゴ糖のHPLC法は、LC-MS 分 析法や第 3 の原理のクロマトグラフィーが実 用化されればより完成された方法となるであ ろう。 